\section{EFFECT OF PRESENT-DAY WHALING ON THE STOCK OF WHALES}

\author{
By J. E. HAMILTON \\ Stanley, Falkland Islands
}

$I^{N}$ November 1946, the Norsk Hvalfangst Tidende (Norwegian Whaling Gazette), which is an authoritative journal, published an article on Antarctic pelagic whaling in the season 1945-46. This article contains the ominous statement ${ }^{1}$ that although the proportion of mature females taken in the catch shows an increase on the seasons immediately preceding the War, the percentage of mature females which were pregnant shows a marked decline. In blue whales, this percentage was only $20 \cdot 7$ per cent and in fin whales $23 \cdot 2$ por cent. Percentages of pregnant females are also given for five pre-war seasons, the lowest figure appearing in 1934-35 and being $28 \cdot 7$ per cent for blue whales and $33 \cdot 1$ per cent for fin whales.

It is generally believed that the cows become pregnant in alternate years, and therefore one might expect about 50 per cent of the adult females to be in calf; or since the newly mature are, in theory at least, pregnant, the percentage might be somewhat higher. How much higher would depend on the pro. portion of newly mature cows to those which had already established the breeding rhythm. A drop in this percentage must be the result of three factors : (1) killing of young mature females before they have had time to be impregnated; (2) depletion of the stock of adult females in previous seasons; and (3) depletion of the total stock of adult whales so that a perceptible number of females are not fertilized.

The 1930-31 season was a record in the annals of pelagic Antarctic whaling, and 28,000 blue whales were taken. Succeeding seasons showed an increasing decline in the quality and quantity of the catch, and consequently in 1937 the minimum lengths at which whales were to be killed were fixed by international agreement. These lengths should be compared with the lengths at which whales become sexually mature; Mackintosh and Wheeler ${ }^{2}$ published the following figures in 1929, and Mackintosh ${ }^{3}$ produced revised lengths in 1942.

$\begin{array}{ccc} & & 1929 \\ \text { Blue whales, male } & 74 \mathrm{ft} .2 \mathrm{in} . \\ \text { Fin } \quad \text {, male } & 77 \mathrm{ft} .9 \mathrm{in} . \\ \text { " } \quad \text { male } & 63 \mathrm{ft} .8 \mathrm{in} . \\ \end{array}$

$74 \mathrm{ft} .2$ in. (no change)

$77 \mathrm{ft} .1$ in. (reduced 8 in.)

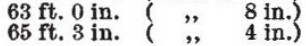

Matthews gives the following lengths for the humpback whale :

$$
\begin{array}{ll}
\text { Males } & 39 \mathrm{ft} .4 \mathrm{in} . \\
\text { Females } & 41 \mathrm{ft} .0 \mathrm{in} .
\end{array}
$$

Now the figures decided upon by international agreement as the minimum for permissible killing are :

$\begin{array}{ll}\text { Blue whales } & \mathbf{7 0} \mathrm{ft} . \\ \text { Fin whales } & \mathbf{5 5} \mathrm{ft} . \\ \text { Humpback whales } & 35 \mathrm{ft} .\end{array}$

In every case the length is well below that at which the animal attains sexual maturity, and consequently the young cows will not have had time to reproduce.
Since the period of gestation is stated to be just over ten months for blue whales and eleven and a half months for fin whales, and the addition of the suckling period of six or seven months gives a total of about eighteen months from conception before the calf can fend for itself ${ }^{2}$, it is obvious that the legal size limit has been fixed too low to be effective in preserving the stock. In fact, the habitual killing of immature whales of both sexes is a particularly and obviously efficient way of exterminating a species, although the effect may not be noticeable until a fair proportion of adults are dead, either naturally or by modern whaling methods.

The season 1940-41 was the last of the 'pre-war' series and the catch was comparatively small; eleven factory ships taking 12,744 blue and fin whales. A number of ships were captured or destroyed, but some of the records, at least, have survived; one factory ship went to the Antarctic whaling grounds in each of the seasons 1943-44 (837 whales) and 1944-45 (1,595 whales). However, speaking generally, there was a 'rest' from the depletion of the stock for four and $a$ half years during 1941-45. In this period, mature females could each have produced two calves and could have become pregnant again by 1945-46, when whaling was resumed on a large scale. Now, in spite of this 'rest', the percentage of blue whales in the 1945-46 catch was only 30.7 per cent, "the lowest hitherto met in pelagic whaling in the Antaretic"'.

The practice of the whalers is to try to catch the largest whales-the gunner who does this gains in reputation; but any whale is better than none, since the factory ships have to be filled with oil. Since the average length of the whales killed is decreasing, it must be concluded that either the larger whales are becoming more difficult to catch or that they have been pretty well killed off. The former assumption cannot stand, for against powerful modern catchers the bolting whale stands no chance. It must take frequent breaths while travelling at speed, remaining practically at the surface all the time, and so can be easily followed and run down. With regard to the latter assumption, the remarks made to me after the last Antarctic season by a very experienced whaler are pertinent. He told me that blue whales were not what they used to be, and that the enormous animals of past years were either extremely scarce or nonexistent I can remember one day in South Shetland when five or six whales were brought in, one male of $89 \mathrm{ft}$., the rest being females all $90 \mathrm{ft}$. or more. The inevitable conclusion is that the larger animals have been killed off, and that the survivors do not live long enough to attain the great size of former years. Absence or rarity of the largest examples of a wild species which is habitually hunted is a sign of a diminishing stock ${ }^{5}$.

In making returns in the whaling industry it is customary to express the catch in 'blue whale units'. This is a deceptive practice, and does not give a true summary of the whales taken. At no time in the history of Antarctic whaling has there been a pure blue whale catch. Two principal species, the blue and fin whales, are hunted and contribute to the catch ; and at one time a third species, the humpback, was also eaught, but now seems to be thoroughly reduced in numbers In the 'blue whale unit' system, the following equivalents are used :

1 blue whale $=2$ fin whales $=2 \frac{\pi}{2}$ humpbacks $=$ 6 sei whales. 
These are valid equivalents; but the important point is this-the agreed figure for the last two whaling seasons of 16,000 'blue whale units' for the contracting parties may well mean that a full catch involves the killing of many more than 16,000 animals. For example, in 1945-46 the Antarctic catch was returned ${ }^{8}$ as $8,304 \cdot 8$ 'blue whale units', but was, in fact, made up of 13,381 whales $(3,604$ blue, 9,184 fin, 238 humpback and 81 sei whales, as well as 239 sperm whales and 35 "sperm and others"). This last might include some bottlenose or Berardius. The catch for 1946-47 has been returned ${ }^{7}$ as $15,230 \cdot 7$ 'blue whale units'. This represents 8,870 blue, 12,857 fin and 2 sei whales, a total of 21,729 whales ${ }^{8}$.

There is obviously a serious danger of losing sight of the reality of the position by continued contempla. tion of the 'blue whale unit' value of a catch, since the number of animals killed will always be greater than the number of units allowed. An industry of this sort cannot be regulated by reference to abstractions, when it depends entirely upon a stock of wild animals, over the lives and breeding habits of which there is no control.

In the presence of vast and unestimated numbers of animals which it is desired to exploit commercially, nothing is easier than to persuade oneself that the stock is so great that it is impossible to injure it, still less to destroy it. But it is my opinion that the stocks of blue whales are showing clear signs of reduction : (1) in the rarity or absence of the huge animals of earlier seasons; (2) in the reduced proportion in the total catch of this species; and (3) in the reduced percentage of mature females which were pregnant. It is also certain that a parallel reduction of the stock of fin whales is now in progress.

The position with regard to sperm whales is somewhat different. These animals are polygamous, and there are therefore spare bulls which can very well be utilized. The sperm whales occurring outside the warm waters of the breeding grounds are almost invariably large males, which have not been able to keep their place in the herds. There is, however, no information as to the size of this stock of spare bulls, or whether they are resident in the Antarctic. Hence, the present increased killing may simply be using up the accumulation of years, either of a resident male stock, or of an annually visitant herd. The appropriate literature is not available here; but I have the clearest recollection that in the days of the old sperm whalers, certain solitary bulls were known to haunt particular areas of the sea, and continued to do so for years. Such whales, like the authentic 'Moby Dick' and 'Paita Tom', attacked boats at sight.

Finally, it may not be out of place to recall to memory the fate of the North American bison and the passenger pigeon. The former was brought to the verge of extinction and the latter completely exterminated by man for commercial purposes, in spite of the almost incredible numbers in which they both existed a little more than a century ago.

${ }^{1}$ Norst Hvalfangst Tidende, No. 11, 278 (1946).

${ }^{2}$ Mackintosh, N. A., and Wheeler, J. F. G., "Southern Blue and Fin Whales", Discovery Reports, 1,417 '(1929).

"Mackintosh, N. A., "The Southern Stock of Whalebone Whales", Discovery Reports, 22, 217 (1942)

"Matthews, L. H., "The Humpback Whale", Discovery Reports, 17, 93 (1937).

s L surie, A. H. "“The Age of Female Blue Whales", Discovery Reports, 15,265 (1937).

- Norst Hvalfangst Tidende, No. 11, 277 (1946).

${ }^{7}$ Norst Hvalfangst Tidende, No. 3, 83 (1947).

${ }^{3}$ Norst Hvalfangst Tidende, No. 9, 322 (1947).

\section{THE ENZYME-SUBSTRATE COM- POUNDS OF CATALASE AND PEROXIDES}

\author{
By BRITTON CHANCE*
}

\author{
Biochemical Department, Medical Nobel Institute, \\ Stockholm, and Molteno Institute, University of \\ Cambridge
}

\begin{abstract}
VATALASE is a hæmatin enzyme found in 1 relatively large concentrations in erythrocytes, liver, kidney, etc. Its extremely efficient catalysis of the destruction of hydrogen peroxide and its ability to catalyse the oxidation of alcohols by hydrogen peroxide have been recognized for some time, but very little direct evidence for the mechanisms of these reactions in terms of the theory of enzyme-substrate compounds has hitherto been obtained.
\end{abstract}

Using a micro form of the method of Hartridge and Roughton ${ }^{1}$ and Millikan ${ }^{2}$ for rapid spectrophotometric studies ${ }^{3}$ of the reaction kinetics and equilibria of the unstable compounds of catalase with hydrogen peroxide and methyl or ethyl hydrogen peroxide, the catalytically active enzyme-substrate compounds of catalase with these substances have been discovered. In addition, corresponding inactive forms of the compounds of catalase with hydrogen peroxide and methyl hydrogen peroxide have been revealed. The catalase-ethyl hydrogen peroxide complex which had previously been studied by Stern is shown to be one of these inactive enzyme-substrate compounds. The three active enzyme-substrate complexes share a common property of oxidizing substances such as alcohols, and in this case catalase functions as a peroxidase. But the active catalase-hydrogen peroxide complex has the unique property of acting 'catalatically', that is, of decomposing hydrogen peroxide directly into water and oxygen. These studies have shed some light on the mechanisms of these reactions.

\section{Spectra of the Primary and Secondary Compounds}

The colour of the three active or primary (I) enzyme-substrate compounds of catalase is pale green, and they have an absorption band at about $670 \mathrm{~m}$.. The Soret band is decreased in intensity and is slightly shifted towards the visible region of the spectrum, giving an isobestic point at about $435 \mathrm{~m} \mu^{5}$. At $405 \mathrm{~m} \mu$ the decrease of extinction coefficient per mole of hæmatin iron bound by peroxide is the same for the three primary com. plexes. Under suitable conditions the green com. pounds change into inactive or secondary (II) red compounds having two bands, at 536 and $572 \mathrm{mu}$, approximately in the positions found by Sterm ${ }^{4}$ for catalase-ethyl hydrogen peroxide. The green-red shift of the hydrogen peroxide compounds superficially resembles that found by Theorell ${ }^{6}$ for horseradish peroxidase and hydrogen peroxide. By analogy with his views, the green primary compounds are ferric iron peroxide complexes with ionic bonds, and the red secondary compounds are ferric iron peroxides with covalent bonds.

\footnotetext{
* John Simon Guggenheim Memorial Fellow.
} 